\title{
Mycoremediation of Petroleum: A Literature Review
}

\author{
Christin Anderson and Glenn Juday \\ School of Natural Resources and Extension, University of Alaska, Alaska 99775, USA
}

\begin{abstract}
Mycoremediation is a cleanup technique within the larger field of bioremediation. In this literature review, the history, species and methods of mycoremediation are investigated. The literature suggests that many fungi have the ability to degrade a wide variety of pollutants. The functional group white-rot fungi have previously been shown to biodegrade petroleum using extracellular enzymes, and have received much popular attention. For this reason, the white-rot basidiomycete Pleurotus ostreatus is the focus of this review. The extracellular enzymes that make mycoremediation possible, fungi's synergy with bacteria, and the effects of temperature are discussed. The authors compare mycoremediation to other bioremediation methods. The authors conclude that environmental factors such as aeration, soil structure, nutrient level and especially temperature, may have stronger effects on petroleum loss than inoculation with white-rot fungi. For volatile pollutants such as diesel, the use of fungal inoculation may be economical only when fungal spawn compost is abundantly available. Composting also may be an inexpensive method to increase temperature, enhancing remediation of hydrocarbons.
\end{abstract}

Key words: Remediation, white-rot, fungi, petroleum, diesel.

\section{Introduction}

Mycoremediation, the process of detoxifying environmental contaminants, is a technique of bioremediation. Bioremediation includes two different approaches, biostimulation and bioaugmentation. Biostimulation is the stimulation of pollutant-degrading microbes that already exist in the environment by aeration, nutrient addition, or changing the environmental conditions in other ways to optimize degradation. Bioaugmentation is the addition of microbes, fungi, or plants to the contaminated area to enhance degradation of target compounds. Bioaugmentation is used when the organisms required to degrade the contaminant are not present, or when they are too sparse to be effective [1]. Culturing and reinoculating the contaminated area with microbes that are already naturally present is thought to be more effective than adding non-native cultivars [2], because the native organisms are presumed to be well suited to other components of their environment. In the context of mycoremediation, fungi isolated

Corresponding author: Glenn Juday, professor, emeritus, main research field: forest ecology. from the environment may be tested to determine whether they are capable of degrading the contaminant, and following studies of autochthonous contaminant-degrading microbes could reveal whether bioaugmentation is required.

\section{Methods}

This review was conducted as part of a project to examine the potential for mycoremediation of soil contaminated by leaking diesel storage tanks in rural Alaska off the road system. Unique challenges to diesel spill cleanup in such circumstances include cold soils and the impracticality or extreme cost of the use of heavy equipment. The review served as a basis for the design of a multifactorial experiment involving the requirements of the commercially available fungal inoculant Pleurotus ostreatus on different substrates at a range of temperatures.

The search began with a review of bioremediation experience in general, especially in circumstances with limited options for large scale mechanical alteration of soil. Lessons learned from previous experience of the Leigh Lab at the University of Alaska Fairbanks in bioremediation of a diesel-contaminated site in Alaska 
provided themes that served as useful guides. The search first examined mycoremediation in general, and then the degradation activity of white rot fungi. Finally, the search focused on available experience with Pleurotus ostreatus, and temperature influence, particularly its activity at cold temperatures.

Specific searches were conducted for the terms "petroleum", "diesel", "degradation" and "bioremediation". To investigate mycoremediation of diesel with Pleurotus ostreatus, the keywords "Pleurotus", "mycoremediation", and "white-rot fungi" were entered into Web of Science. Combinations of keywords and the addition of "temperature", "cold" or "arctic" were used to search for temperature effects. Finally, useful leads were obtained in this fast-developing field from the Alaska Oil Spill Technology Symposium.

\section{Results and Discussion}

\subsection{History}

The ability of fungi to break down phenols and aromatic hydrocarbons in wood has been known for decades. In the 1960s, Dr. Horst Lyr described ligninolytic degradation by white rot fungi [3]. White rot fungi are wood decomposers that preferentially degrade lignin, leaving behind pulpy, white cellulose and hemicellulose. Bumpus [4] expanded on these initial findings, hypothesizing that white rot fungi could degrade persistent xenobiotics, which have carbon skeletons similar to lignin. Bumpus evaluated the chemical breakdown of polychlorinated biphenyls, trinitrotoluene (TNT), dioxins, and lindane by Phanerochaete chrysosporium.

Phanerochaete chrysosporium was the first popular white rot fungal species used to degrade pollutants. Most ensuing mycoremediation research initially evaluated Phanerochaete chrysosporium and its closely related species. White rot fungi are believed to be the only group of organisms capable of completely mineralizing lignin [5]. However, further research has revealed that many different groups of fungi are capable of at least partially degrading lignin and similar hydrocarbons, including the coprophilic Agaricus bisporus [6], the mycorrhizal Glomus caledonium [7], the airborne Aspergillus fumigatus [8], the black yeast Exophiala xenobiotica [9], a lichen [10] and many other species [5, 10-13].

As investigations of mycoremediation have proceeded, the breadth of pollutants fungi known to degrade has also increased. In addition to petroleum and polycyclic aromatic hydrocarbons, white rot fungi were also found to degrade explosives, pesticides, polychlorinated biphenyls, synthetic dyes, and creosote [14]. Fungi that could live on the pollutant alone, without co-metabolism, were discovered subsisting on volatile organic hydrocarbons [9] and polyurethane [15].

As documentation of additional fungal species and pollutants they degraded grew, a new field emerged, and the term "mycoremediation" was coined in 2005 by Paul Stamets.

Mycoremediation refers to any method of detoxifying pollutants using fungi. The concept of mycoremediation came to popular public attention as a result of several TED talks by Stamets and the creation of the website and book "Radical Mycology" by Paul McCoy [16].

\subsection{Mycoremediation Potential}

Many oil-degrading fungi have been isolated from the environment, some of which are more effective than bacteria in completely degrading crude oil [11, 17]. Studies that are more recent have found that microfungi such as ascomycetes [8], Cladosporium sp. [18], Penicillium sp. and other deuteromycetes [19] isolated from the environment can degrade hydrocarbons. However, in nearly all of these studies of fungal degradation of petroleum products, the species examined were microfungi. Most white rot fungi are basidiomycetes, which consist of a mycelial network that can draw water and nutrients throughout the substrate. In addition, the structure of 
basidiomycete mycelia allows the organism to bridge gaps between patches of pollutant, instead of requiring continual contact with the pollutant as a growth substrate [12]. For pollutants that are patchily distributed, the ability to co-metabolize the pollutant and another substrate is an advantage.

Pleurotus ostreatus has many desirable properties as a species for mycoremediation. It is a versatile white rot basidiomycete that has been proven successful in degrading petroleum in many studies [20-27]. Pleurotus ostreatus produces a wide range of enzymes active against a broad range of compounds. $P$. ostreatus has the ability to transport water, nutrients, bacteria and the contaminants themselves along the mycelium, sharing resources for contaminant degradation throughout the soil matrix. Finally, $P$. ostreatus has the ability to span air-filled gaps in soil and penetrate micropores, and co-metabolize non-toxic organic molecules, allowing the fungus to remain active in conditions hostile to bacterial growth [28].

However, the application of $P$. ostreatus in mycoremediation has a number of disadvantages. First, the fungus requires an aerobic environment. Second, once established, the mycelia are sensitive to disturbance. Standard methods of bioremediation that aerate by tilling are designed for microorganisms, and would damage the mycelium by breaking it up. Lastly, $P$. ostreatus requires a lignocellulose amendment, since it is a wood rotting fungus, and may not compete well with native soil fungi and bacteria without its principle substrate [12].

A mycoremediation study involving P. ostreatus, popularized by Paul Stamets in Mycelium Running [29], involved layering diesel-contaminated soil with P. ostreatus straw spawn in large, 10 cubic yard mounds covered in shade cloth. Other mounds were mixed with nitrogen fertilizer and left uncovered, or inoculated with bacteria plus nitrogen fertilizer and covered with polyethylene tarps. Over 16 weeks, the mycelienated mounds lost their oily smell, turned lighter in appearance, and began to grow vascular plants and secondary decomposer fungi. The control and other treatments did not significantly change appearance or smell. Although this informal study showed potential, important questions remained; there was such heterogeneous diesel distribution in the soil that the authors could not conclude that there was any difference between the treatments when testing for total petroleum hydrocarbons. Analysis of individual PAHs was initiated, but not completed due to a lack of funding [30].

A more carefully controlled laboratory study by Novotný et al. [24] found that P. ostreatus degraded PAHs better than other two white rot fungi tested. Anthracene, pyrene and phenanthrene decreased by 81-87 percent, $84-93$ percent, and 41-63 percent in 2 months, respectively, with the $P$. ostreatus treatment. Subsequent lab and bench studies chose P. ostreatus as an organism for bioremediation of PAHs [20, 21]. Another study of mycoremediation with P. ostreatus reported an 85 percent to 90 percent loss of total petroleum hydrocarbons after 4 weeks of incubation, but lacked any statistical analysis verifying that petroleum loss within a 95\% confidence interval [27].

Another set of mycoremediation studies capitalized upon the need to dispose of fungal spawn as a waste byproduct of mushroom cultivation. Using two applications of waste $P$. ostreatus spawn to contaminated soil, Eggen and Šašek [31] saw an 87 to 99 percent degradation of PAHs in 12 weeks, and Okparanma et al. [25] observed an 80 to 92 percent PAH loss over 8 weeks. Gasecka et al. [32] used spent Agaricus bisporus and Lentinula edodes compost to degrade PAHs by 63 percent to 87 percent in 12 weeks. Mycoremediation appears to offer an excellent use of aged fungal spawn that would otherwise be wasted by the mushroom cultivation industry.

In general, those mycoremediation studies examining the degradation of specific PAHs have found significant modification and mineralization by fungal treatments $[21,24,32]$. However, three 
mycoremediation studies measuring total petroleum hydrocarbon degradation [22, 27, 30] had too much uncertainty to determine whether there was a significant difference between the fungal treatments and controls.

\subsection{Enzymes: How It works}

In examining the potential for mycoremediation, a key question is how fungi achieve the breakdown of pollutants. The common ligninolytic enzymes in white rot fungi are laccases and peroxidases [33]. They are both extracellular proteins that catalyze hydrocarbon degradation using free radicals, molecules with single unpaired valence electrons. Laccases oxidize oxygen to release a free radical, and peroxidases oxidize hydrogen peroxide, $\mathrm{Mn}^{2}$ or $\mathrm{Mn}^{3}$ to release free radicals [12]. The free radicals indiscriminately cleave bonds, breaking straight chain hydrocarbons or opening aromatic rings, thereby making hydrocarbons more bioavailable for uptake and biodegradation by fungi, bacteria and other degraders [34]. In fungi, some metabolites are also taken into the hyphae and further degraded with cytochrome P450 [12]. With their cocktail of non-specific enzymes, white rot fungi are some of the only organisms able to completely mineralize hydrocarbons [5].

Performance of laccases and peroxidases can be affected by environmental conditions. Lignin degradation appears to be stimulated more as a response to nutrient depletion than to the presence of pollutant [35]. Ligninolytic enzyme production is greatest during the fungal vegetative growth stage and decreases sharply during fruiting [33]. Laccase activity can be increased by warm temperatures [35]. Laccase production can be inhibited by low availability of copper, since copper is an important constituent of laccase [36]. However, not all laccases contain four copper atoms; one isolated from $\mathrm{P}$. ostreatus contained one copper atom, one zinc atom, and two iron atoms instead [37].

Incomplete mineralization can yield toxic metabolites [13, 38]. Quinones are common metabolites of PAHs, and some can be more toxic than the initial compound. Ligninolytic enzymes can further mineralize quinones, or make them more bioavailable to degradation by bacteria [39]. The intracellular cytochrome P450 enzymes are also able to degrade smaller metabolites into completely mineralized carbon dioxide, water and proteins [12].

\subsection{Synergy with Bacteria}

Although white rot fungi are able to completely mineralize hydrocarbons, more commonly they perform only the initial attack, breaking open hydrocarbon chains and rings to make the compounds more available to microbial decomposition. During a 60 day study of petroleum bioremediation, Chen, et al. [7] found that Glomus caledonium and Bacillus subtilis, used together, removed 92.6 percent of total petroleum hydrocarbon while autochthonous microorganisms removed only 21.9 percent, and the combined effect was greater than the sum of individual removal by each in pure culture. In some species, the mycelia form rhizomorphs that can conduct water throughout the soil, carrying bacteria to otherwise inaccessible areas [40]. Li, et al. [41] observed a synergistic effect of Mycobacterium and filamentous fungi, with diesel loss increasing from 20.9 percent and 34 percent separately to 99 percent together over a 5-day treatment.

\subsection{Temperature}

Most studies on mycoremediation were conducted at room temperature $\left(\sim 25^{\circ} \mathrm{C}\right)$. No studies were found specifically evaluating the effect of a range of temperatures, including low temperatures characteristic of ambient condition in northern soils, on mycoremediation. However, studies on other methods of bioremediation at different temperatures are useful for guiding mycoremediation design.

Low temperatures inhibit bioremediation of hydrocarbons due to their lower volatility and reduced 
microbial metabolism [42-45]. The average optimal temperature for standard bioremediation is considered to be $30{ }^{\circ} \mathrm{C}$ [46], although bioremediation at cold temperatures is possible. A study on sub-Antarctic soils found that even at $4{ }^{\circ} \mathrm{C}$, a treatment with fertilizer was associated with a 75 percent reduction of diesel in 180 days. Additionally, at the conclusion of the study, soil toxicity was lower at $4{ }^{\circ} \mathrm{C}$ than at 10 ${ }^{\circ} \mathrm{C}$ or $20{ }^{\circ} \mathrm{C}$ [47]. In Antarctic soils at $4{ }^{\circ} \mathrm{C}$, biostimulation with nutrients was effective in degrading 98 percent of alkanes within 18 weeks. In that study, augmentation with native bacteria was only effective at removing 45 percent of alkanes, most likely due to nutrient limitations. In cold Antarctic soils the more toxic PAHs remained longer than 12 weeks [48]. Naphthalene, the lightest PAH, was mineralized at a rate of 4.02 percent per day at $8{ }^{\circ} \mathrm{C}$ with nitrogen fertilization in Antarctic soil [49]. In general, relatively little is known about PAH biodegradation at cold temperatures in soil [44].

A few mycoremediation field studies have been conducted over a long enough period of time to include cold temperature seasonal periods. Ambient temperature at a study using Phanerochaete sordida on creosote sludge fluctuated between $21{ }^{\circ} \mathrm{C}$ and $38^{\circ} \mathrm{C}$ for the first 45 days, and then dropped to $15{ }^{\circ} \mathrm{C}$ and below. Even with cooler temperatures, PAH depletion was more rapid in fungal-treated soil than in controls [50]. Another study in Finland using $P$. velutina had temperatures ranging from $6{ }^{\circ} \mathrm{C}$ to $23{ }^{\circ} \mathrm{C}$ inside the soil piles [51]. In the lab scale, fungal amendment enhanced degradation of PAHs, but did not have a significant effect in the field scale soil piles. The authors hypothesized that since there was a lower PAH concentration in the field scale than in the lab $(1,400 \mathrm{mg} / \mathrm{kg}$ versus $3,500 \mathrm{mg} / \mathrm{kg})$, the field soil was found to be less toxic and native bacteria were better able to perform bioremediation. There was a dramatic improvement in quality in field soils over six weeks. In spite of the cool temperatures, the entire bioavailable fraction of PAHs was degraded in three months.
In summary, the available literature indicates that white rot fungal amendment to soil along with a lignocellulose source may enhance petroleum degradation at low temperatures. The addition of limited nutrients, especially nitrogen, also appears to speed up bioremediation at low temperatures.

\subsection{Mycoremediation in the Context of Bioremediation Methods}

The method used for treating petroleum spills is determined by soil type. Bioremediation methods can be either in-situ or ex-situ. Since ex-situ methods require excavation, they are usually an order of magnitude greater in cost than in-situ methods.

A commonly used bioremediation method is land farming, which involves excavating the soil and spreading it out over a sealed base, then aerating and fertilizing it to promote biodegradation. Biopiling is another standard ex-situ method in which soil is heaped and mixed with some kind of bulking agent like crop residue or bark, and sometimes nutrients or microorganisms [52]. Biosparging or venting is an in-situ method of injecting air or nutrients into the soil at the contaminated site to stimulate microbes [53]. Phytoremediation is an experimental method of planting vegetation in contaminated soil to stimulate microbial degradation in the rhizosphere and facilitate extraction of soluble or volatile contaminants [53].

Williams [52] observed that the use of bioremediation is growing rapidly, as it is relatively low-cost and involves less drastic modification of the environment than standard treatments. Land farming ranges from $\$ 50-\$ 75 /$ ton of soil, biopiling is $\$ 8-\$ 25 /$ ton, biosparging costs $\$ 10-\$ 75 /$ ton, and phytoremediation ranges from $\$ 10-\$ 480 /$ ton $[52,53]$. Mycoremediation in Washington State is estimated to cost $\$ 13.5 /$ ton, excluding the cost of monitoring and lab studies [30].

Twin studies by Cajthaml et al. [54] and Bhatt et al. [55] concluded that composting is "substantially more efficient in removing all PAHs, including higher 
molecular weight ones, than fungal treatment". However, the two studies differed in some important respects, raising the question of whether they are indeed comparable. The Cajthaml study used a higher ratio of amendment to soil than the Bhatt study. Cajthaml mixed 2,832 mg/kg PAH-contaminated soil with compost consisting of wheat straw, chicken manure and gypsum, at a ratio of 1:4 soil to compost. Bhatt used a ratio of 2.5:1 soil to spawn. The Cajthaml treatment was likely better aerated. The compost chamber dimensions were $1.3 \times 1.35 \times 2.5 \mathrm{~m}$, with aeration tubes. Bhatt et al. [55] layered the same contaminated soil with straw colonized with mycelium in one-liter Erlenmeyer flasks. The Cajthaml treatment was large enough to achieve a thermogenic effect, as opposed to Bhatt's smaller treatment. Temperatures in Cajthaml et al.'s composting study exceeded $60{ }^{\circ} \mathrm{C}$ in the first 6 days, and then gradually cooled as metabolism slowed over the next 36 days versus a steady $26^{\circ} \mathrm{C}$ for 14 weeks in Bhatt's study. In the Cajthaml study, composting yielded a 42 to 68 percent degradation of 3-4 ring PAHs and 35 to 57 percent degradation of higher mass PAHs, whereas in the Bhatt study, flask mycoremediation yielded to 62 percent degradation of 3-4 ring PAHs and no reported analysis of higher molecular weight PAHs. An experiment comparing larger-scale compost treatments with and without addition of fungal spawn would control for temperature differences and better address the question of whether mycoremediation enhances petroleum degradation.

Some studies indicate that composting does enhance petroleum degradation compared to conventional land-farming techniques. Guerin [56] found that composting resulted in 50 percent loss of PAHs, whereas land farming with or without added organic matter only resulted in 5 percent loss. The greater rate of PAH loss in the compost treatment was associated with higher temperatures. The compost treatment reached higher temperatures, up to $42{ }^{\circ} \mathrm{C}$, than the land farming treatment, and remained stable day and night. The maximum temperatures in the land farming treatments were $26{ }^{\circ} \mathrm{C}$ and $27{ }^{\circ} \mathrm{C}$. In the lab-scale compost treatments, soil temperature did not exceed $28{ }^{\circ} \mathrm{C}$ (room temperature) because the thermal mass was too small to allow thermogenesis. Organic matter was reduced over time, and the proportion of lignin detected by the Klasson method (acid soluble lignin) increased, indicating a paucity of lignin-degrading fungi.

\section{Conclusion}

Warming the ground is one of the most effective treatments for promoting biodegradation, especially in cold climates, and heaping or composting can be a cost-effective way to warm the substrate [52, 57, 58]. Research has yet to determine whether amending with ligninolytic fungi would enhance degradation of toxic pollutants in such a favorable, warm environment.

No studies were found on the success of mycoremediation at cold temperatures. Many studies found that mycoremediation did significantly enhance degradation of pollutants under controlled conditions, but for actually performing clean-up in the field, other environmental factors appear to have a greater impact. Environmental engineers should consider using mycoremediation if the mycelienated substrate is available for free or at nominal cost, as in waste from a mushroom growing facility, or if the contaminant cannot be degraded by native microbes. Non-volatile contaminants that cannot be easily broken down by bacteria are good candidates for future mycoremediation research.

\section{Acknowledgements}

Financial support was provided by the McIntire Stennis Cooperative Forestry Research program project ALK 13-04, and NSF Grant DEB 0620579 for Bonanza Creek LTER.

Thank you to Dr. Mary Beth Leigh, Associate Professor of Microbiology with the Institute of Arctic 
Biology, for providing writing support and an inspiring lab community. Thank you to Dr. David Valentine, Professor of Forest Soils in the School of Natural Resources and Extension, for his encouragement and guidance.

\section{References}

[1] EPA (Environmental Protection Agency). 2014. "Bioremediation Overview." Office of Superfund Remediation and Technology Innovation. Accessed Feberary 24, 2014. http://www.cluin.org/techfocus/default.focus/sec/Bioremediation/cat/Ov erview/.

[2] Hosokawa, R., Nagai, M., Morikawa, M., and Okuyama, H. 2009. "Autochthonous Bioaugmentation and Its Possible Application to Oil Spills." World Journal of Microbiology and Biotechnology 25: 1519-1528.

[3] Lyr, H. 1963. "Enzymatische Detoxification Chlorieter Phenole." Journal of Phytopathology 47:73-83.

[4] Bumpus, J. A., Tien, M., Wright, D., and Aust, S. D. 1985. "Oxidation of Persistent Environmental Pollutants by White Rot Fungus.” Science 228 (4706): 1434-1436.

[5] Anastasi, A., Tigini, V., and Varese, G. C. 2013. "The Bioremediation Potential of Different Ecophysiological Groups of Fungi." In Fungi as Bioremediators, edited by Goltapeh, E. M., Y. R. Danesh, and A. Varma. Berlin: Verlag Berlin Heidelberg.

[6] ten Have, R., Wijngaard, H., Ariës-Kronenburg, N. A., Straatsma, G., and Schapp, P. J. 2003. "Lignin Degradation by Agaricus bisporus Accounts for a $30 \%$ Increase in Bioavailable Holocellulose during Cultivation on Compost." Journal of Agricultural and Food Chemistry 51 (8): 2242-5.

[7] Chen, L., Chen, W., Chen, L., and Chen, Y. 2009. "Study on Fungi-Bacteria Augmented Remediation of Petroleum Contaminated Soil from Northwest of China." Journal of Food, Agriculture and Environment 7, 3-4. pt. 2:750-753.

[8] Bento, F. M., Beech, I. B., Gaylarde, C. C., Englert, G. E., and Muller, I. L. 2005. "Degradation and Corrosive Activities of Fungi in a Diesel-Mild Steel-Aqueous System." World Journal of Microbiology and Biotechnology 21 (2): 5-142.

[9] Isola, D., Selbmann, L., Sybren de Hoog, G., Fenice, M., Onofri, S., Prenafeta-Boldú, F. X., et al. 2013. "Isolation and Screening of Black Fungi as Degraders of Volatile Aromatic Hydrocarbons.” Mycopathologia 175: 369-379.

[10] Lee, K. M., Gimore, D. F., and Huss, M. J. 2005. "Fungal Degradation of the Bioplastic PHB." Journal of Polymers and the Environment 13 (3): 213-219.

[11] Davies J. S., and Westlake, D. W. 1979. "Crude Oil
Utilization by Fungi." Canadian Journal of Microbiology 25 (2): 146-156.

[12] Harms, H., Schlosser, D., and Wick, L. Y. 2011. "Untapped Potential: Exploiting Fungi in Bioremediation of Hazardous Chemicals." Nature Reviews: Microbiology 9: 117-192.

[13] Pinedo-Rivilla, C., Aleu, J., and Collado, I. G. 2009. "Pollutants Biodegradation by Fungi." Current Organic Chemistry 13: 1194-1214.

[14] Pointing, S. B. 2001. "Feasibility of Bioremediation by White-Rot Fungi." Applied Microbiology and Biotechnology 57: 20-33.

[15] Russell, J. R., Huang, J., Anand, P., Kucera, K., Sandoval, A. G., Dantzler, K. W., et al. 2011. "Biodegradation of Polyester Polyurethane by Endophytic Fungi." Applied and Environmental Microbiology 77 (17): 6076.

[16] McCoy, P. 2016. Radical Mycology. Portland: Chthaeus Press.

[17] Cerniglia, C. E., and Perry, J. J. 1973. "Crude Oil Degradation by Microorganisms Isolated from the Marine Environment." The Journal of Basic Microbiology (4): 299-306.

[18] Giraud, F., Guiraud, P., Kadri, M., Blake, G., and Steiman, R. 2001. "Biodegradation of Anthracene and Fluoranthene by Fungi Isolated from an Experimental Constructed Wetland for Wastewater Treatment." Water Research 35 (17): 4126-46.

[19] Prenafeta-Boldu, F. X., Kuhn, A., Luykx, D. M. A. M., Anke, H., van Groenestijn, J. W., and de Bont, J. A. M. 2001. "Isolation and Characterisation of Fungi Growing on Volatile Aromatics Hydrocarbons as their Sole Carbon and Energy Source." Mycological Research 105 (4): 477-484.

[20] Leonardi, V., Šašek, V., Petruccioli, M., D’Annibale, A., Erbanová, P., and Cajthaml, T. 2006. "Bioavailability Modification and Fungal Biodegredation of PAHs in Aged Industrial Soils." International Biodeterioration \& Biodegradation 60: 165-170.

[21] Márquez-Rocha, F. J., Hernández-Rodríguez, V. Z., and Vázquez-Duhalt, R. 2000. "Biodegradation of Soil-Adsorbed Polycyclic aromatic Hydrocarbons by the White Rot Fungus Pleurotus ostreatus.” Biotechnology Letters 22: 469-472.

[22] Meysami, P., and Baheri, H. 2003. "Pre-Screening of Fungi and Bulking Agents for Contaminated Soil Bioremediation.” Advances in Environmental Research 7 (4): 881-887.

[23] Novotný, Č., Svobodová, K., Erbanová, P., Cajthaml, T., Kasinath, A., Lang, E., et al. 2004. "Ligninolytic Fungi in Bioremediation: Extracellular Enzyme Production and Degradation Rate." Soil Biology \& Biochemistry 36: 1545-1551. 
[24] Novotný, Č., Erbanová, P., Šašek, V., Kubátová, A., Cajthaml, T., Lang, E., et al. 1999. "Extracellular Oxidative Enzyme Production and PAH Removal in Soil by Exploratory Mycelium of White Rot Fungi." Biodegradation 10: 159-16.

[25] Okparanma, R. N., Ayotamuno, J. M., Davis, D. D., and Allagoa, M. 2011. "Mycoremediation of Polycyclic Aromatic Hydrocarbons (PAH)-Contaminated Oil-Based Drill-Cuttings.” African Journal of Biotechnology 10 (26): 5149-5156.

[26] Young, D., Rice, J., Martin, R., Lindquist, E., Lipzen, A., Grigoriev, I., et al. 2015. "Degradation of Bunker C Fuel Oil by White-Rot Fungi in Sawdust Cultures Suggests Potential Applications in Bioremediation." PLoS ONE $10 \quad$ (6): 10130381. doi:10.1371/journal.pone.0130381.

[27] Zitte, L. F., Awi-Waadu, G. D. B., and John, A. U. 2012. "Effect of Oyster Mushroom (Pleurotus ostreatus) Mycelia on Petroleum Hydrocarbon Contaminated Substrate." Journal of Agriculture and Social Research 12 (2):115-121.

[28] Wick, L. Y., Furuno, S., and Harms, H. 2010. Handbook of Hydrocarbon Microbiology Edited by Timmis, K. N., McGenity, T., van der Meer, J. R. and de Lorenzo, V. New York: Springer.

[29] Stamets, P. 2005. Mycelium Running. Berkeley: Ten Speed Press.

[30] Thomas, S., Becker, P., Pinza, M. R., and Word, J. Q. 1998. "Mycoremediation of Aged Petroleum Hydrocarbon Contaminants in Soil." Prepared by Battelle Marine Sciences Laboratory for the Washington State Department of Transportation.

[31] Eggen, T., and Šašek, V. 2002. "Use of Edible and Medicinal Oyster Mushroom (Pleurotus ostreatus (Jacq.: Fr.) Kumm.) Spent Compost in Remediation of Chemically Polluted Soil." International Journal of Medicinal Mushrooms 4 (3): 255-261.

[32] Gasecka, M., Drzewiecka, K., Stachowiak, J., Siwulski, M., Golinski, P., and Sobieralski, K. 2013. "The Efficient Degradation of Selected PAHs in Soil with a Substrate Refuse from Pleurotus ostreatus Cultivation." Fresenius Environmental Bulletin 22:9a: 2651-2658.

[33] Elisashavili, V., Kachlishvili, E., and Penninckx, M. J. 2008. "Lignocellulolytic Enzymes Profile During Growth and Fruiting of Pleurotus ostreatus on Wheat Straw and Tree Leaves." Acta Microbiologica et Immunologica Hungarica 55 (2): 157-168.

[34] Meulenberg, R., Rijnaarts, H. H. M., Doddema, H. J., and Field, J. A. 1997. "Partially Oxidized Polycyclic Aromatic Hydrocarbons Show an Increased Bioavailability and Biodegradability." FEMS Microbiology Letters 152: 45-49.
[35] Madhavi, V., and Lele, S. S. 2009. "Laccase: Properties and Applications." Bioresources 4 (4): 1694-1717.

[36] Tychanowitcz, G. K., de Souza, D. F., Souza, C. G. M., Kadowaki, M. K., and Peralta, R. M. 2006. "Copper Improves the Production of Laccase by the White-Rot Fungus Pleurotus pulmonarius in Solid State Fermentation." Brazilian Archives of Biology and Technology 49 (5): 699-704.

[37] Palmieri, G., Giardina, P., Bianco, C., Scaloni, A., Capasso, A., and Sannia, G. 1997. "A Novel White Laccase from Pleurotus ostreatus." The Journal of Biological Chemistry 272 (50): 301-307.

[38] Atlas, R. M. 1995. "Petroleum Biodegradation and Oil Spill Bioremediation." Marine Pollution Bulletin 31 (4-12): 178-182.

[39] Pozdnyakova, N. 2012. "Involvement of the Ligninolytic System of White-Rot and Litter- Decomposing Fungi in the Degradation of Polycyclic Aromatic Hydrocarbons." Biotechnology Research International 2012: 1-20.

[40] Kohlmeier, S., Smits, T. H. M., Ford, R. M., Keel, C., Harms, H., and Wick, L. Y. 2005. "Taking the Fungal Highway: Mobilization of Pollutant-Degrading Bacteria by Fungi." Environmental Science and Technology 39: 4640-4646.

[41] Li, Y. Q., Liu, H. F., Tian, Z. L., Zhu, L. H., Wu, Y. H., and Tang, H. Q. 2008. "Diesel Pollution Biodegradation: Synergetic Effect of Mycobacterium and Filamentous Fungi." Biomedical and Environmental Sciences 21 (3): 181-187.

[42] Atlas, R. M. 1981. "Microbial Degradation of Petroleum Hydrocarbons: An Environmental Perspective." Microbiological Reviews 45 (1): 180-209.

[43] Horel, A. 2009. "Investigation of the Physical and Chemical Parameters Affecting Biodegradation of Diesel and Synthetic Diesel Fuel Contaminating Alaskan Soils." Cold Regions Science and Technology 58 (3): 1-119.

[44] Margesin, R., and Schinner, F. 2001. "Biodegradation and Bioremediation of Hydrocarbons in Extreme Environments." Applied Microbiology and Biotechnology 56: 650-663.

[45] Yang, S., Jin, H., Wei, Z., He, R., Ji, Y., Li, X., et al. 2009. "Bioremediation of Oil Spills in Cold Environments: A Review.” Pedosphere 19 (3): 371-381.

[46] Das, N., and Chandran, P. 2011. "Microbial Degradation of Petroleum Hydrocarbons: An Overview." Biotechnology Research International 2011: 1-13. doi:10.4061/2011/941810.

[47] Coulon, F., Pelletier, E., Gourhant, L., and Delille, D. 2005. "Effects of Nutrient and Temperature on Degradation of Petroleum Hydrocarbons in Contaminated Sub-Antarctic Soil." Chemosphere 58: 1439-1448.

[48] Stallwood, B., Shears, J., Williams, P. A., and Hughes, K. 
A. 2005. "Low Temperature Bioremediation of Oil-Contaminated Soil Using Biostimulation and Bioaugmentation with a Pseudomonas sp. from Maritime Antarctica." Journal of Applied Microbiology 99 (4): 794-802.

[49] Aislabie, J., McLeod, M., and Fraser, R. 1998. "Potential for Biodegradation of Hydrocarbons in Soil from the Ross Dependency, Antarctica." Applied Microbiology and Biotechnology 49: 210-214.

[50] Davis, M. W., Glaser, J. A., Evans, J. W., and Lamar, R. T. 1993. "Field Evaluation of the Lignin- Degrading Fungus Phanerochaete sordida to Treat Creosote-Contaminated Soil." Environmental Science and Technology 27: 2572-2576.

[51] Winquist, E., Björklöf, K., Schultz, E., Räsänen, M., Salonen, K., Anasonye, F., Cajthaml, T., Steffen, K. T., Jørgensen, K. S., and Tuomela, M. 2014. "Bioremediation of PAH-Contaminated Soil with FungiFrom Laboratory to Field Scale." International Biodeterioration \& Biodegradation 86: 238-247.

[52] Williams, J. 2006. "Bioremediation of Contaminated Soils: A Comparison of in Situ and ex Situ Techniques." Accessed December 6, 2013. http://www.public. iastate.edu/ tge/courses/ce521/jera.pdf.

[53] Khan, F. I., Husain, T., and Hejazi, R. 2004. "An Overview and Analysis of Site Remediation Technologies." Journal of Environmental Management 71: $95-122$.

[54] Cajthaml, T., Bhatt, M., Šašek, V., and Mateju, V. 2002. "Bioremediation of PAH-Contaminated Soil by Composting: A Case Study." Folia Microbiologia 47 (6): 696-700.

[55] Bhatt, M., Cajthaml, T., and Šašek, V. 2002. "Mycoremediation of PAH Contaminated Soil." Folia Microbiologia 47 (3): 255-258.

[56] Guerin, T. F. 2000. "The Differential Removal of Aged Polycyclic Aromatic Hydrocarbons from Soil during Bioremediation." Environmental Science and Pollution Research 7 (1): 19-26.

[57] Filler, D. M., and Carlson, R. F. 2000. "Thermal Insulation Systems for Bioremediation in Cold Regions." Journal of Cold Regions Engineering 14 (3): 119-129.

[58] Semple, K. T., Reid, B. J., and Fermor, T. R. 2001. "Impact of Composting Strategies on the Treatment of Soils Contaminated with Organic Pollutants." Environmental Pollution 112: 269-283. 